\title{
Why does the Namib Desert tenebrionid Onymacris unguicularis (Coleoptera: Tenebrionidae) fog-bask?
}

\author{
STRINIVASAN G. NAIDU \\ Department of Physiology, Nelson R. Mandela School of Medicine, University of KwaZulu-Natal, 719 Umbilo Road, Durban 4041, \\ South Africa; e-mail: naidus15@ukzn.ac.za
}

Key words. Water balance, osmoregulation, lipid, glycerol, Tenebrionidae, Onymacris unguicularis, Namib Desert

\begin{abstract}
Dehydration of Onymacris unguicularis (Haag) for 10 days at $27^{\circ} \mathrm{C}$ resulted in a weight loss of $14.9 \%$, and a $37 \%$ decrease in haemolymph volume. Although there was an overall decrease in the lipid content during this period, metabolic water production was insufficient to maintain total body water (TBW). Rehydration resulted in increases in body weight (6.2\% of initial weight), TBW (to normality), and haemolymph volume (sub-normal at the end of rehydration). Despite an increase of $44.0 \mathrm{mg}$ in the wet weight of $O$. unguicularis after drinking for $1 \mathrm{~h}$, there was little change in the water content at this time, although the total lipid content increased significantly. Increases in haemolymph osmolality, sodium, potassium, chloride, amino acid and total sugar concentrations during dehydration were subject to osmoregulatory control. No evidence of an active amino acid-soluble protein interchange was noted during dehydration or rehydration. Haemolymph trehalose levels were significantly increased at the end of rehydration (relative to immediate pre-rehydration values), indicating de novo sugar synthesis at this time. Osmotic and ionic regulation was evident during rehydration, but control of OP during haemolymph-dilution is poor and accomplished largely by the addition to the haemolymph of free amino acids and solute(s) not measured in this study. There was little mobilization of sodium and chloride ions from storage sites at this time. The lesser osmoregulatory ability of Onymacris unguicularis and perhaps earlier susceptibility to osmotic stress, a significantly high normal blood glycerol level (relative to other diurnal adesmiine tenebrionids), and a water storage mechanism associated with synthesis of fat, probably all contribute to the development of fog-basking behaviour in this species. Water gain in $O$. unguicularis during periods of relative drought is probably largely accomplished by a greater food consumption.
\end{abstract}

\section{INTRODUCTION}

Onymacris unguicularis are unique amongst diurnal Namib tenebrionids in the water-trapping behaviour they display during fogs. "Fog-basking", as it is termed, consists of the beetles adopting a characteristic head-down stance on the dune crests, and facing into the fog-laden wind; water from the fog condenses on the dorsum and then trickles down to the mouth where the condensate is imbibed (Hamilton \& Seely, 1976; Seely, 1979). Strikingly, fog-basking frequently occurs outside of the normal activity period of this species, at ambient temperatures and wind velocities far removed from their preferences, and they are not known to seek food at these times. O. unguicularis are ordinarily diurnal, demonstrate a bimodal foraging regime (feeding mainly on wind-blown plant detritus - Seely et al., 1983; Louw et al., 1986), and maintain elevated day-time body temperatures ranging from $30-40^{\circ} \mathrm{C}$ (Hamilton, 1975; Hamilton \& Seely, 1976; Seely et al., 1988). However, they emerge from the sand of dune slipfaces (where they normally remain buried overnight) and climb to the crests to fog-bask during nocturnal fogs, when ambient temperatures may be lower than $3^{\circ} \mathrm{C}$ and surface temperatures as low as $1^{\circ} \mathrm{C}$ (Hamilton \& Seely, 1976; Robinson \& Seely, 1980; Cooper, 1982; Seely, 1983). In it's response to fogs, the species appears to be facultatively crepuscular.

Why this species undergoes such an elaborate ritual to obtain fog-water, has been the subject of much speculation. Possibilities engendered for its occurrence include a requirement for water balance (Seely, 1979) and reproduction (Cooper, 1982; Hattingh et al., 1984). Since other adult diurnal tenebrionids in the Namib do not display fog-basking behaviour; and, since many of those species examined for an osmoregulatory ability, are known to osmoregulate efficiently (Nicolson, 1980; Naidu, 2001), we decided to investigate the possibility that $O$. unguicularis might be endowed with a lesser capability in this regard. To this end, we subjected Onymacris unguicularis (Haag) to a dehydration-rehydration regimen, and examined water balance parameters and blood chemistry. In view of the fact that the strictly nocturnal tenebrionid Stips stali was shown to possess very high levels of blood glycerol (Naidu, 1998), the cryo-protective properties of which were suggested to enable this species' nocturnal activities during low night-time desert temperatures, we further hypothesized that if $O$. unguicularis were indeed poor osmoregulators, then the possession of high blood glycerol levels might enable them to exploit an environmental-specific climatic situation which was not normally theirs to take advantage of. Although many polyols (sorbitol, mannitol, erythritol, threitol, ethylene glycol) and sugars (glucose, sucrose, trehalose) are used to provide antifreeze protection, glycerol occupies a favoured position among insects for a variety of reasons (Storey \& Storey, 2005). In this regard, we also measured blood glycerol levels in this species during dehydration and rehydration. 


\section{MATERIAL AND METHODS}

Adult beetles were collected in vegetationless dune fields (slipfaces) near Rooibank, approximately $40 \mathrm{~km}$ west of the desert ecological research unit (DERU) at Gobabeb (Namibia, South West Africa). They were flown to Johannesburg and maintained in glass terraria partly filled with Namib sand, in a controlled laboratory environment $\left(28 \pm 2^{\circ} \mathrm{C} ; 12 \mathrm{~h} / 12 \mathrm{~h} ; 35 \pm\right.$ $11 \%$ r.h.) for 3 weeks prior to investigation. The beetles were fed fresh lettuce and oatmeal.

Both male and female beetles were used in the study (weight range: $370-1000 \mathrm{mg} ; \mathrm{M} \pm \mathrm{SE}$ : $700.9 \pm 15.7 \mathrm{mg}$ ). For dehydration, the beetles were weighed and placed in a desiccator over silica gel (10-15\% r.h.; measured with a Barigo hygrometer), for a period of 10 days at $27^{\circ} \mathrm{C}$. After this they were allowed to drink distilled water to repletion, and maintained at 50-60\% r.h. for a further 4 days (drinking permitted).

Beetles were weighed every second day to the nearest $0.1 \mathrm{mg}$ (Sauter). Water content was determined by freeze-drying. Total lipids were determined gravimetrically after removal of haemolymph and freeze-drying (Lyophilizer) to obtain final dry weights. Lipid content in the dried specimens was estimated by extraction with three changes $(24 \mathrm{~h}$ each) of a $2: 1$ methanolchloroform mixture $(\mathrm{v} / \mathrm{v})$ at room temperature, with a final freeze-drying providing fat-free dry weights (Nicolson, 1980). The total lipid content (dry weight - fat-free dry weight) was expressed as a percentage of fat-free dry weight i.e.

$$
\frac{\text { lipid content }}{\text { FFDW }} \times \frac{100}{1}
$$

Haemolymph samples were collected from the coxa or directly from the dorsal vessel (after careful removal of the elytra) into capillary tubes. This was done at approximately the same time every 2 days during the course of dehydration and rehydration. Haemolymph was taken once only from each insect, and haemolymph volume was determined according to the gravimetric method of Richardson et al. (1931), and expressed as $\mu 1 / \mathrm{mg}$ fat-free dry weight ( $\mu 1 / \mathrm{mg}$ FFDW) to reduce variance due to differences in weight, water and fat contents. The method consists of dissecting the weighed insect and removing the haemolymph with absorbent tissue before reweighing. It is useful when haemolymph volume is small or reduced by dehydration (Wall, 1970; Tucker, 1977a; Nicolson, 1980), and has been shown to produce more consistent results than the ${ }^{14} \mathrm{C}$-inulin method (Levenbook, 1958) in blood volume determinations of the blister beetle $C$. armatus (Cohen et al., 1986). Individual samples were analysed for osmolality (Wescor 5120B vapour pressure osmometer), chloride, sodium and potassium concentrations (Radiometer CMT10 chloride titrator for chloride and FLM3 flame photometer for sodium and potassium), and for total protein according to the method of Lowry et al. (1951) using bovine serum albumin as standard (Naidu, 2001). Haemolymph sugars and glycerol were determined by gas chromatography, as described previously (Naidu, 1998), and total amino acids were determined by a modified ninhydrin assay described earlier (Naidu, 1998).

The results were analysed statistically using a one-way analysis of variance $(\alpha=0.05)$, with pairwise comparison between groups employing Duncan's Multiple Range test.

\section{RESULTS}

\section{Weight changes during dehydration and rehydration}

The weight changes in $O$. unguicularis during dehydration and rehydration are shown in Fig. 1A. At the end of 10 days of dehydration, the mean weight of $O$. unguicularis had decreased by $14.92 \% \pm 0.76 \%(\mathrm{P}<0.05)$.
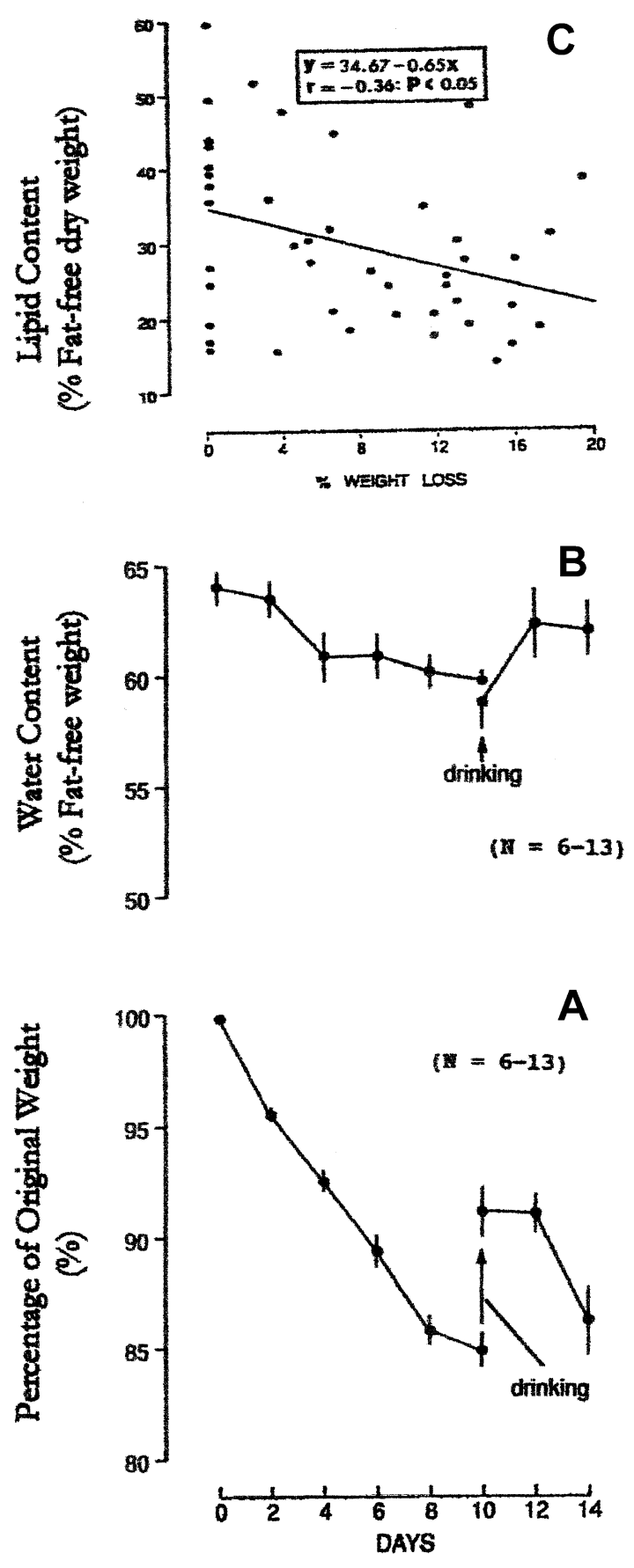

Fig. 1. Weight (A) and water content (B) of O. unguicularis during dehydration and rehydration $(N=6-13 ; \mathrm{M} \pm \mathrm{SE})$, and changes in lipid content $(\mathrm{C})$ as a function of percentage weight lost during dehydration.

Drinking (day 10) resulted in a mean weight increase of $44.0 \mathrm{mg}$ (about $6.2 \%$ of initial body weight), which was insufficient to raise body weight to Control (day 0) values $(\mathrm{P}<0.05)$. Further rehydration (day 12) caused no increase in body weight, with the body weight on day 14 falling to immediate pre-rehydration (day 10) weights ( $\mathrm{P}$ $>0.05$, relative to day 10 of dehydration). The mean value on day 14 was significantly lower than on days 10 ( $1 \mathrm{~h}$ after drinking) and day 12. 
TABLE 1. Total lipid contents in O. unguicularis during dehydration and rehydration (expressed as percentage of fat-free dry weight).

\begin{tabular}{|c|c|c|c|c|c|c|c|c|}
\hline \multicolumn{9}{|c|}{ Total lipid $(\%)^{\mathrm{a}}$} \\
\hline \multicolumn{6}{|c|}{ Dehydration (days) } & \multicolumn{3}{|c|}{ Rehydration (h) } \\
\hline 0 & 2 & 4 & 6 & 8 & 10 & 1 & 48 & 96 \\
\hline $34.8 \pm 3.7$ & $34.5 \pm 3.6$ & $24.3 \pm 4.3$ & $33.5 \pm 5.0$ & $21.0 \pm 2.4$ & $26.7 \pm 2.9$ & $35.2 \pm 3.8$ & $17.2 \pm 1.6$ & $25.4 \pm 3.9$ \\
\hline
\end{tabular}

\section{Water content}

In Fig. 1B is shown the water content of Onymacris, during the period of dehydration and rehydration, expressed as percentage of fat-free weight. The initial water content of $64.1 \pm 0.8 \%$ (day 0 ) dropped significantly $(\mathrm{P}<0.01)$ during dehydration to $60.0 \pm 0.4 \%$ (day $10)$. No significant change in TBW $(\mathrm{P}>0.05)$ was observed $1 \mathrm{~h}$ after drinking $(59.0 \pm 1.2 \%)$, but values on days $12(62.6 \pm 1.6 \%)$ and $14(62.3 \pm 1.2 \%)$ were increased to the extent that they were not significantly different from the Control $(\mathrm{P}>0.05)$.

\section{Lipid content}

When the lipid content of $O$. unguicularis, expressed as percentage of fat-free dry weight is plotted against weight loss of individual beetles (Fig. 1C), a significant negative correlation is found $(\mathrm{P}<0.05)$, indicating an overall decrease in the lipid content of this species with the progressive weight loss of dehydration. However, an examination of mean lipid contents $(\mathrm{N}=6-13)$ during dehydration and rehydration (Table 1), shows an apparent increase in total lipid content between days 4 and 6 of dehydration $(\mathrm{P}>0.05)$ and between days 8 and 10 of dehydration $(\mathrm{P}>0.05)$, and a significant increase in this parameter $1 \mathrm{~h}$ after drinking $(\mathrm{P}<0.05)$, suggesting lipid synthesis at these times.

\section{Haemolymph volume}

Changes in haemolymph volume of this species, expressed as $\mu \mathrm{l} / \mathrm{mg}$ FFDW, are shown in Fig. 2A. The volume of haemolymph in $O$. unguicularis decreased over the period of dehydration, from $0.52 \pm 0.02 \mu 1 / \mathrm{mg}$ FFDW on day 0 to $0.33 \pm 0.02 \mu \mathrm{l} / \mathrm{mg}$ FFDW on day 10 $(\mathrm{P}<0.05)$. Although the haemolymph volume appeared to increase $1 \mathrm{~h}$ after drinking $(0.38 \pm 0.06 \mu \mathrm{l} / \mathrm{mg}$ FFDW $)$, the change was insignificant $(\mathrm{P}>0.05)$. One-way
ANOVA shows that the haemolymph volume on day 12 $(0.50 \pm 0.09 \mu \mathrm{l} / \mathrm{mg}$ FFDW $)$ is significantly increased $(\mathrm{P}<$ 0.05 , relative to day 10 of dehydration), however, and not different from the Control $(\mathrm{P}>0.05)$. Haemolymph volume decreases from day 12 to day 14 in this species $(\mathrm{P}$ $<0.05)$, and the value on day $14(0.35 \pm 0.04 \mu \mathrm{lmg}$ FFDW) is considerably lower than the Control $(\mathrm{P}<0.05)$ and not statistically different from values on day 10 (before and after drinking).

\section{Haemolymph osmolality}

Haemolymph osmolality increased significantly $(\mathrm{P}<$ 0.05 ) during dehydration (Fig. 2B), from $417.0 \pm 2.7$ $\mathrm{mOsm} / \mathrm{kg}$ on day 0 to $506.3 \pm 28.4 \mathrm{mOsm} / \mathrm{kg}$ on day 10 (21\% change). A tendency to decrease was apparent $1 \mathrm{~h}$ after drinking $(491.0 \pm 15.8 \mathrm{mOsm} / \mathrm{kg} ; \mathrm{P}>0.05$, relative to immediate pre-rehydration values), but the value at this time was still significantly higher than the Control $(\mathrm{P}<$ $0.05)$. The osmolality dropped sharply on day $12(434.0 \pm$ $15.0 \mathrm{mOsm} / \mathrm{kg} ; \mathrm{P}<0.05$, relative to values on day 10 before and after drinking), and was not statistically different from the Control at this time $(\mathrm{P}>0.05)$. However, on day $14(476.7 \pm 21.2 \mathrm{mOsm} / \mathrm{kg})$, the haemolymph osmolality was found to be elevated to immediate prerehydration values $(\mathrm{P}>0.05$, relative to values on day 10 before and after drinking), and significantly higher than both day 12 and Control values $(\mathrm{P}<0.05)$.

\section{Sodium concentration}

The sodium concentration (Fig. 2C), initially $115 \pm 1.6$ $\mathrm{mM}$ (day 0$)$, increased gradually and significantly $(\mathrm{P}<$ $0.05)$ up to day $6(135.3 \pm 2.3 \mathrm{mM})$, after which it remained at this elevated level until day $10(132.7 \pm 5.7$ $\mathrm{mM})$. When given water on day $10(1 \mathrm{~h})$, the sodium concentration dropped to $106.7 \pm 6.8 \mathrm{mM}$ (not significantly different from the Control), but in the ensuing period of

TABLE 2. Regulation of haemolymph organic and inorganic solutes in Onymacris unguicularis during dehydration.

\begin{tabular}{|c|c|c|c|}
\hline \multirow{4}{*}{ Haemolymph volume $(\mu \mathrm{l})^{\mathrm{a}}$} & \multicolumn{3}{|c|}{ Dehydration } \\
\hline & \multirow{3}{*}{$\begin{array}{c}\text { Start (day 0) } \\
116.6 \\
\end{array}$} & \multicolumn{2}{|c|}{ End (day 10) } \\
\hline & & \multicolumn{2}{|c|}{71.2} \\
\hline & & Observed & Expected $^{\mathrm{b}}$ \\
\hline Sodium (mM) & 115.6 & 132.7 & 189.3 \\
\hline Potassium (mM) & 17.7 & 19.7 & 29.0 \\
\hline Chloride (mM) & 116.8 & 165 & 191.3 \\
\hline Amino acid (mM) & 54.6 & 58.8 & 89.4 \\
\hline Trehalose $(\mathrm{mM})$ & 62.7 & 36.7 & 102.7 \\
\hline Glucose $(\mathrm{mM})$ & 1.2 & 1.0 & 2.0 \\
\hline Glycerol (mM) & 10.4 & 12.5 & 17.0 \\
\hline
\end{tabular}

${ }^{\mathrm{a}}$ In a standard beetle of initial weight $700.9 \mathrm{mg} .{ }^{\mathrm{b}}$ Increase expected from simple haemolymph-concentration. 

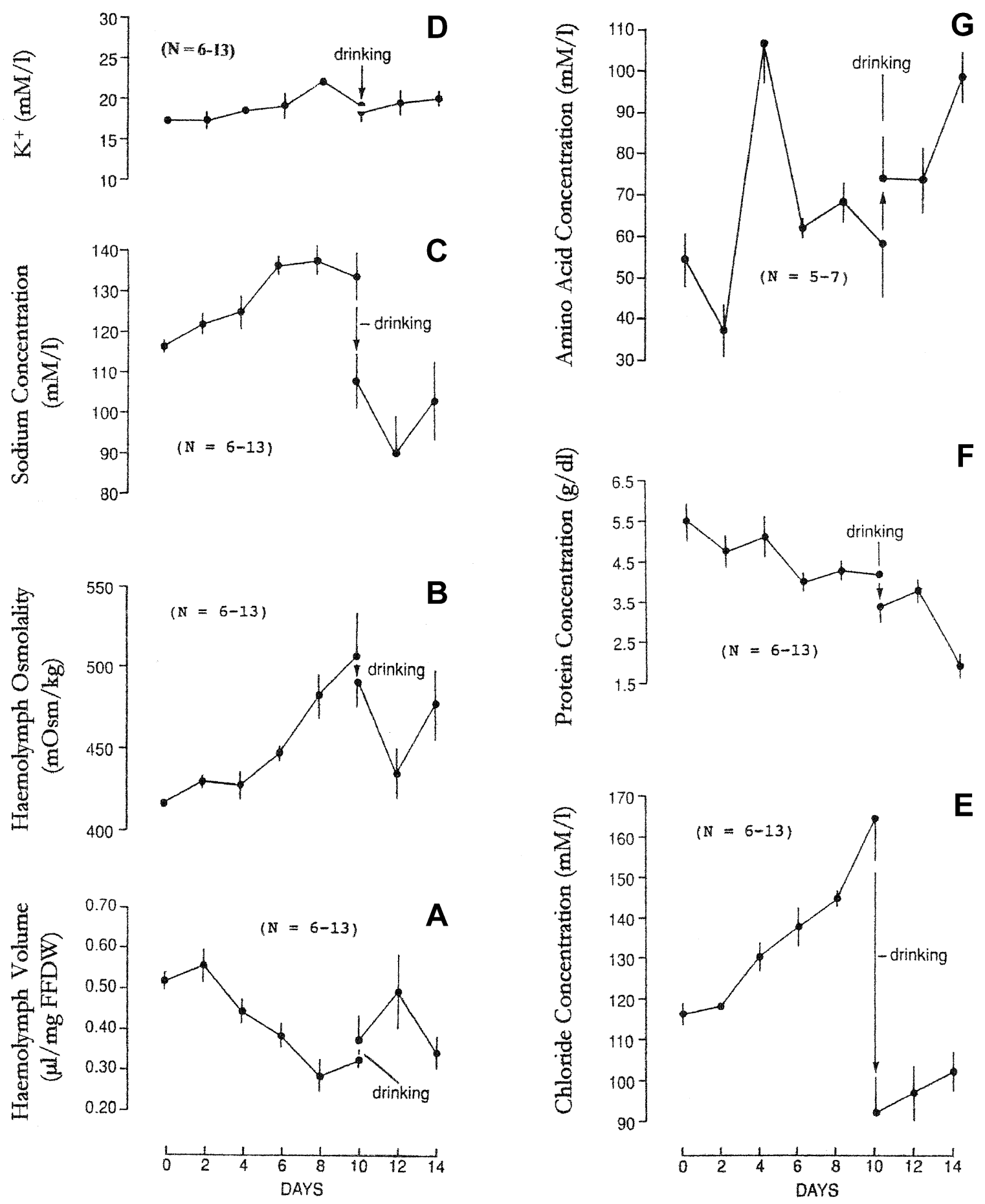

Fig. 2. Effects of dehydration and rehydration on haemolymph volume (A), osmolality (B), sodium (C), potassium (D), chloride (E), protein $(F)$, and amino acids (G). Drinking shown by arrow. Vertical lines represent \pm one standard error of the mean. Where SEs are not shown, symbols exceed size of SEs.

rehydration the sodium concentration was found to be depressed even further (day 12: $88.8 \pm 9.4 \mathrm{mM} ; \mathrm{P}<0.05$, relative to the Control). On day 14 , however, the sodium concentration was higher $(101.5 \pm 9.7 \mathrm{mM})$, and not statistically different from the Control $(\mathrm{P}>0.05)$. Variability between individuals was much higher during rehydration.

\section{Potassium concentration}

The haemolymph potassium concentration of this species (Fig. 2D), initially $17.7 \pm 0.7 \mathrm{mM}$, was not signifi- cantly different $(\mathrm{P}>0.05)$ after 10 days of dehydration (day 10: $19.7 \pm 0.7 \mathrm{mM}$ ), although one-way ANOVA did show that the potassium level on day $8(22.6 \pm 0.7 \mathrm{mM})$ was significantly higher than those on days 0,2 and 4 (P $<0.05)$. Drinking $(1 \mathrm{~h})$ did not significantly affect the potassium concentration $(\mathrm{P}>0.05$, relative to immediate pre-rehydration values), and all values during the rehydration period were not statistically different from the Control $(\mathrm{P}>0.05)$. 
TABLE 3. Regulation of haemolymph organic and inorganic solutes in Onymacris unguicularis during rehydration.

\begin{tabular}{|c|c|c|c|}
\hline \multirow{4}{*}{ Haemolymph volume $(\mu l)^{a}$} & \multicolumn{3}{|c|}{ Rehydration } \\
\hline & \multirow{3}{*}{$\begin{array}{c}\text { Before (day 10) } \\
71.2\end{array}$} & \multicolumn{2}{|c|}{ After (48 h) } \\
\hline & & \multicolumn{2}{|c|}{112.3} \\
\hline & & Observed & Expected $^{\mathrm{b}}$ \\
\hline Sodium (mM) & 132.7 & 88.8 & 84.1 \\
\hline Potassium (mM) & 19.7 & 20.1 & 12.5 \\
\hline Chloride (mM) & 165.0 & 97.7 & 104.6 \\
\hline Amino acid (mM) & 58.8 & 74.0 & 37.3 \\
\hline Trehalose $(\mathrm{mM})$ & 36.7 & 22.2 & 23.3 \\
\hline Glucose (mM) & 1.0 & 0.9 & 0.6 \\
\hline Glycerol (mM) & 12.5 & 13.3 & 7.9 \\
\hline
\end{tabular}

${ }^{\mathrm{a}}$ In a standard beetle of initial weight $700.9 \mathrm{mg} .{ }^{\mathrm{b}}$ Decrease expected from simple haemolymph-dilution.

\section{Chloride concentration}

The haemolymph chloride concentration in O. unguicularis increased significantly during dehydration (Fig. 2E), from $116.8 \pm 2.8 \mathrm{mM}$ on day 0 to $165.0 \pm 10.5 \mathrm{mM}$ on day $10(\mathrm{P}<0.05)$. Drinking $(1 \mathrm{~h})$ resulted in a sharp drop in the chloride concentration (day 10, $1 \mathrm{~h}$ after drinking: $92.3 \pm 6.9 \mathrm{mM} ; \mathrm{P}<0.05$, relative to both immediate prerehydration and Control values). However, there was a tendency for the anion concentration to increase during the rehydration period (day 12: $97.7 \pm 6.5 \mathrm{mM}$; day 14 : $102.7 \pm 4.9 \mathrm{mM}$ ), with one-way ANOVA showing the concentration on day 14 not to be significantly different from the Control $(\mathrm{P}>0.05)$.

\section{Protein concentration}

The haemolymph protein concentration in Onymacris decreased significantly during dehydration (Fig. 2F), from $5.51 \pm 0.45 \mathrm{~g} / \mathrm{dl}$ on day 0 to $4.16 \pm 0.06 \mathrm{~g} / \mathrm{dl}$ on day $10(\mathrm{P}<0.05)$. The concentrations at $1 \mathrm{~h}$ and $48 \mathrm{~h}$ after drinking were not significantly different from immediate pre-rehydration values $(\mathrm{P}>0.05)$, and still significantly lower than the Control $(\mathrm{P}<0.05)$. On day 14 , the haemolymph protein concentration was found to have dropped significantly $(\mathrm{P}<0.05)$, and lower than both values on days 10 ( $1 \mathrm{~h}$ after drinking) and 12 of rehydration, as well as from the Control $(\mathrm{P}<0.05)$.

\section{Amino acid concentration}

Haemolymph total amino acid concentrations in this species during dehydration and rehydration are shown in Fig. 2G. The haemolymph amino acid concentration in $O$. unguicularis is not significantly altered after 10 days of dehydration (day 0: $54.6 \pm 6.5 \mathrm{mM}$; day 10: $58.8 \pm 13.1$ $\mathrm{mM} ; \mathrm{P}>0.05)$. However, the level appears to decrease after 2 days of dehydration (not significant), and then increase maximally on day $4(106.8 \pm 9.3 \mathrm{mM})$ when it is significantly higher than values on days $0,2,6,8$ and 10 $(\mathrm{P}<0.05)$. While one-way ANOVA shows amino acid concentrations at $1 \mathrm{~h}$ and $48 \mathrm{~h}$ after drinking not to be significantly different from either pre-rehydration or Control values $(\mathrm{P}>0.05)$, the concentration is significantly increased on day $14(99.6 \pm 6.3 \mathrm{mM} ; \mathrm{P}<0.05$, relative to both immediate pre-rehydration and Control values).

\section{Sugar concentrations}

Trehalose and glucose were the only carbohydrates present in significant amounts in the haemolymph of $O$. unguicularis (Fig 3A). Haemolymph trehalose, initially $62.7 \pm 8.0 \mathrm{mM}$ (day 0 ), decreases progressively up to day $6(11.3 \pm 2.5 \mathrm{mM} ; \mathrm{P}<0.05$, relative to the Control $)$, when the concentration is lowest during the dehydration period. The concentration is greatly elevated on day 8 (50.0 \pm $10.5 \mathrm{mM} ; \mathrm{P}<0.05$, relative to concentrations on days 4 and 6) when it is not statistically different from the Control $(\mathrm{P}>0.05)$, but drops on day $10(36.7 \pm 7.1 \mathrm{mM}$; $\mathrm{P}<$ 0.05 , relative to day 0$)$. No significant difference was found in the haemolymph trehalose level $1 \mathrm{~h}$ after drinking $(37.3 \pm 4.6 \mathrm{mM} ; \mathrm{P}>0.05$, relative to day 10 of dehydration) and although a tendency to decrease was apparent on day $12(22.2 \pm 2.4 \mathrm{mM})$, the concentration at this time (day 12) was similarly not significantly different from immediate pre-rehydration values $(\mathrm{P}>0.05)$. The trehalose concentration was significantly increased, however, on day 14 of rehydration $(85.7 \pm 6.9 \mathrm{mM}$; $\mathrm{P}<0.05$, relative to both immediate pre-rehydration and Control values).

Despite a tendency for the glucose concentration to increase on day 8 of dehydration $(2.6 \pm 0.8 \mathrm{mM})$,

TABLE 4. Haemolymph osmoregulation in Onymacris unguicularis during dehydration and rehydration.

\begin{tabular}{|c|c|c|c|c|c|c|c|}
\hline & \multicolumn{5}{|c|}{ Dehydration (days) } & \multirow{2}{*}{\multicolumn{2}{|c|}{$\begin{array}{c}\text { Rehydration (h) } \\
48\end{array}$}} \\
\hline & 0 & & & & & & \\
\hline \multirow[t]{2}{*}{$\mathrm{HV}(\mu \mathrm{l})$} & 116.6 & \multicolumn{2}{|c|}{84.2} & \multicolumn{2}{|c|}{71.2} & \multicolumn{2}{|c|}{112.3} \\
\hline & & Obs & Exp $^{\mathrm{a}}$ & Obs & $\operatorname{Exp}^{\mathrm{a}}$ & Obs & $\operatorname{Exp}^{b}$ \\
\hline Osmolality (mOsm/kg) & 417.0 & 446.7 & 577.5 & 506.3 & 682.9 & 434.0 & 321.0 \\
\hline
\end{tabular}

HV - haemolymph volume; Obs - observed osmolality; Exp ${ }^{\mathrm{a}}$ - expected from simple haemolymph concentration; Exp ${ }^{\mathrm{b}}-$ expected from simple haemolymph dilution. 

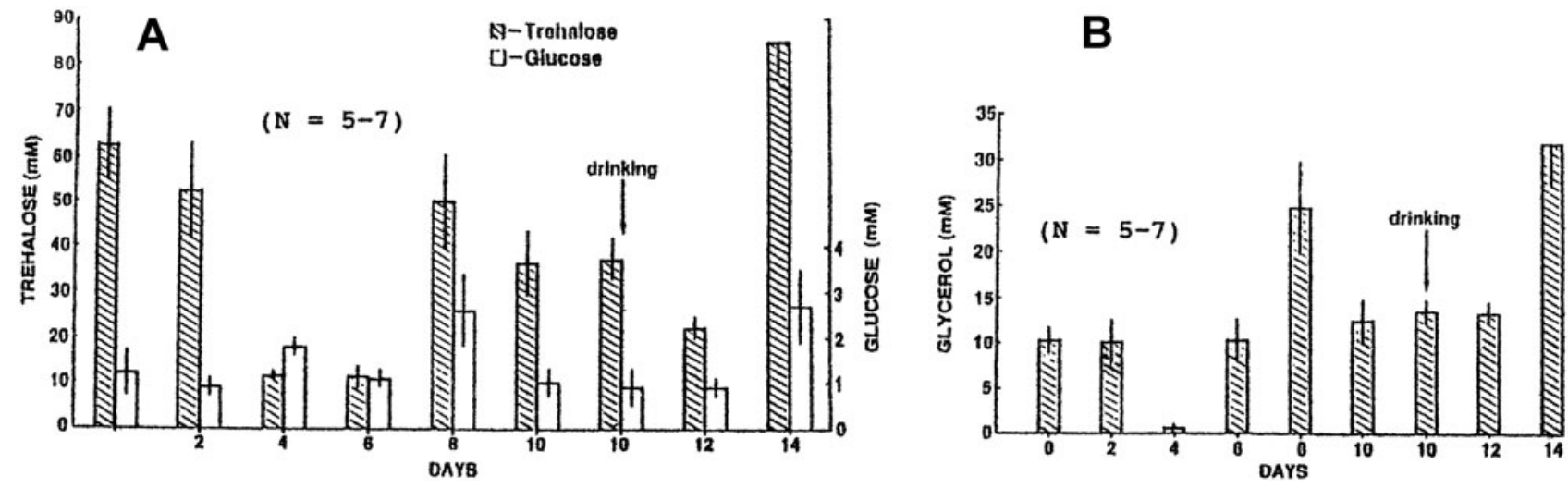

Fig. 3. Effects of dehydration and rehydration on haemolymph trehalose and glucose (A), and glycerol (B). Drinking shown by arrow. Vertical lines represent \pm one standard error of the mean

one-way ANOVA shows that glucose concentrations in the haemolymph of $O$. unguicularis are not significantly changed during dehydration (day $0: 1.2 \pm 0.5 \mathrm{mM}$; day 10: $1.0 \pm 0.3 \mathrm{mM} ; \mathrm{P}>0.05)$. There is no change in the glucose concentration $48 \mathrm{~h}$ after drinking is first permitted (day 10, $1 \mathrm{~h}$ after drinking: $0.9 \pm 0.35 \mathrm{mM}$; day 12: $0.9 \pm$ $0.16 \mathrm{mM} ; \mathrm{P}>0.05$, relative to immediate pre-rehydration values), although the concentration is found to be significantly increased on day $14(2.7 \pm 0.8 \mathrm{mM} ; \mathrm{P}<0.05$, relative to both immediate pre-rehydration and Control values).

\section{Glycerol concentration}

Glycerol concentrations in the haemolymph of $O$. unguicularis are shown in Fig. 3B. The haemolymph glycerol concentration in this species is not significantly changed after 10 days of dehydration (day $0: 10.4 \pm 1.5 \mathrm{mM}$; day 10: $12.5 \pm 2.4 \mathrm{mM} ; \mathrm{P}>0.05)$, although one-way ANOVA shows the concentration on day $8(24.8 \pm 5.1$ $\mathrm{mM})$ to be significantly increased $(\mathrm{P}<0.05$, relative to the Control and all concentrations during the dehydration period). Drinking does not significantly alter the glycerol concentration on days 10 and 12 (day $10,1 \mathrm{~h}$ after drinking: $13.5 \pm 1.3 \mathrm{mM}$; day $12: 13.3 \pm 1.2 \mathrm{mM}$ ), although the concentration is found to be greatly increased on day 14 $(31.9 \pm 4.7 \mathrm{mM} ; \mathrm{P}<0.05$, relative to both immediate prerehydration and Control values).

\section{Regulation of haemolymph solute and osmoregulation}

The observed values for the measured haemolymph constituents (relative to that expected from simple haemolymph concentration) indicate that all of these substances are removed from the haemolymph of $O$. unguicularis during dehydration (Table 2). While most solutes are added to the haemolymph during drinking (observed values relative to that expected from simple haemolymph dilution), there is little addition of sodium and chloride at this time (Table 3).

Although haemolymph osmoregulation is considerable in the early stages of dehydration (days 0 to 6), the capacity to regulate haemolymph solute is not great when haemolymph volume losses are greater (day 10, Table 4). On day 6 of dehydration, the observed change in haemolymph osmolality is $18.5 \%$ of that expected in the absence of osmoregulation; on day 10 , the actual change in osmolality is $33.6 \%$ of that expected in the absence of osmoregulation. During rehydration, haemolymph osmoregulation is not substantial (Table 4). After $48 \mathrm{~h}$ of drinking, the observed change in haemolymph osmolality is $39 \%$ of that expected in the absence of solute regulation.

\section{DISCUSSION}

O. unguicularis occurs in the vegetationless dune fields of the Namib Desert (one of the 3 major biotopes), are ordinarily day-active, (Holm \& Edney, 1973; Hamilton \& Seely, 1976; Seely et al., 1983) are ultrapsammophilous (Holm \& Edney, 1973), and swim through the sand as if it were a fluid medium, not forming true burrows (Louw et al., 1986). As noted earlier, they demonstrate a bimodal foraging regime (timed for late morning and early afternoon - M.K. Seely, pers. comm.), and feed mainly on wind-blown plant detritus (Seely et al., 1983; Louw et al., 1986).

After 10 days of dehydration at $27^{\circ} \mathrm{C}$, the mean weight of O. unguicularis was reduced by $14.9 \%$. After drinking

TABLE 5. Changes in weight and water contents of Onymacris unguicularis after drinking for $1 \mathrm{~h}$ (standard insect).

\begin{tabular}{|c|c|c|c|c|c|c|c|c|}
\hline \multirow{2}{*}{ Time } & \multicolumn{2}{|r|}{ Weight } & \multicolumn{2}{|c|}{ FFDW } & \multicolumn{2}{|r|}{ Fat } & \multicolumn{2}{|c|}{ TBW } \\
\hline & $\mathrm{mg}$ & $\%$ Orig. wt. & $\mathrm{mg}$ & $\% \mathrm{WW}$ & $\mathrm{mg}$ & $\%$ FFDW & $\mathrm{mg}$ & $\%$ FFW \\
\hline Day 10 (D) & 596.3 & $85.08 \pm 0.76$ & 215.9 & $36.2 \pm 0.71$ & 57.6 & $26.7 \pm 2.90$ & 322.8 & $60.0 \pm 0.44$ \\
\hline Day $10(\mathrm{R})$ & 640.3 & $91.35 \pm 1.11$ & 229.2 & $35.8 \pm 0.92$ & 80.7 & $35.2 \pm 3.81$ & 330.4 & $59.0 \pm 1.19$ \\
\hline Gain $^{\mathrm{a}}$ & \multicolumn{2}{|r|}{+44.0} & \multicolumn{2}{|c|}{+13.3} & \multicolumn{2}{|r|}{+23.1} & \multicolumn{2}{|r|}{+7.6} \\
\hline
\end{tabular}

D - dehydration; R - rehydration; FFDW - fat-free dry weight; TBW - total body water; \% Orig. wt. - \% original weight; \% WW $\%$ wet weight; \% FFW - \% fat-free weight. ${ }^{a}$ After drinking for $1 \mathrm{~h}$. 
for $1 \mathrm{~h}$ during the rehydration period, O. unguicularis showed a mean weight gain of $6.2 \%$ of initial body weight, but this was insufficient to raise body weight to normal. Rapid weight gains by drinking have also been shown for other desert tenebrionids (Broza et al., 1976; Nicolson, 1980). Further rehydration did not increase body weight in $O$. unguicularis, with body weight decreasing significantly in this species between $1 \mathrm{~h}$ and $96 \mathrm{~h}$ after drinking. Tucker (1977a) also found that if water alone was given to dehydrated Periplaneta during the rehydration period, the cockroaches never regain their original weight. Body weight was also shown to decrease in the tenebrionid Onymacris plana (after initially returning to normal), in the period following drinking (Nicolson, 1980).

The weight loss in $O$. unguicularis during dehydration is not the result of water loss alone. During 10 days of dehydration the mean loss of dry weight was $28.9 \mathrm{mg}$ (including faeces). The loss of dry material is due to an overall loss of $20.5 \mathrm{mg}$ of lipid (which correlates closely with estimates from the lipid-weight loss regression line (Fig. 1C): the total lipid extractable with methanolchloroform decreased from 34.7 to $25.0 \%$ fat-free dry weight, which represents a decline of $23.8 \mathrm{mg}$ i.e. from 77.8 to $54.0 \mathrm{mg}$ ). Thus, it may tentatively be assumed that $20.5 \mathrm{mg}$ of lipid is metabolized during dehydration, producing approximately $21.9 \mathrm{mg}$ of oxidation water. Other insects which draw on reserve lipids during periods of desiccation are the cockroach $P$. americana (Tucker, 1977b) and tenebrionid beetles O. plana (Nicolson, 1980) and $S$. gracilipes (Naidu, 2001). The water obtained from the oxidation of reserve foodstuffs, represents an important water source for insects with no access to free water (Edney, 1957; refs in Edney, 1977). As determined in this study, however, the total water content in dehydrated beetles is lower than in hydrated ones (Fig. 1B). Thus, while the metabolic water contribution (by lipid oxidation) in $O$. unguicularis is substantial, it is not sufficient to maintain water balance when this species is dehydrated for a period of 10 days. A similar situation was found for dehydrating P. americana (Tucker, 1977b), in which lipid reserves decreased by $19 \%$ (extraction in acetone) but the total water contents of dehydrated cockroaches were still significantly lower than Controls.

The change in the water content of $O$. unguicularis after drinking for $1 \mathrm{~h}$, is not commensurate with the weight gain (presumed water uptake) noted for this species at this time (Table 5).

Although $O$. unguicularis consumes $44.0 \mathrm{mg}$ of water (increase in wet weight after drinking for $1 \mathrm{~h}$ ), only 7.6 $\mathrm{mg}$ of water is added to the existing water present; however, the total lipid content and fat-free dry weight are found to increase substantially (by $23.1 \mathrm{mg}$ and $13.3 \mathrm{mg}$, respectively) at this time. Thus, in this species, there appears to be synthesis of lipid (as well as dry material other than lipid) immediately upon drinking. This suggests that water taken up by $O$. unguicularis, when faced with a relative abundance of it, may be stored by synthesis of fat. Although not directly comparable, de novo triglyceride synthesis in starved Aedes sollicitans has been shown to occur at a rate of approx $0.61 \%$ of body weight per hour (measured after $24 \mathrm{~h}$ - Van Handel, $1965)$, with the species accumulating a total amount of $67 \%$ of its dry weight in fat within 6 days. And, after normalizing for body size, larger insects are found to synthesize much greater amounts of lipid than do smaller ones. The rate of $3.59 \%$ of body weight after $1 \mathrm{~h}(23 \mathrm{mg} / 640$ $\mathrm{mg}$ ) shown for lipid synthesis in O. unguicularis is approx 5.9 times that determined for Ae. sollicitans, but $O$. unguicularis is a considerably larger species (approx. 180 times by weight). Evidence for water storage by fat synthesis may be found in studies conducted on the cockroaches Leucophaea and Periplaneta. In both Leucophaea (Scheurer \& Leuthold, 1969) and Periplaneta (Verret \& Mills, 1973, 1975a, b), large amounts of water are taken up several days before its incorporation into developing eggs. In the interval between uptake and incorporation into eggs, storage of the imbibed water has been suggested to occur in the fat body and integument (Verret \& Mills, 1975a). That a high concentration of ATP is found in the fat body at the time of maximum water release [Lüscher \& Wyss-Huber, 1966 (cited in Edney, 1977)], has led to the suggestion that the imbibed water is stored by fat synthesis, with release of the stored water occurring by lipid oxidation (Edney, 1977). Possible building blocks for fatty acid synthesis in $O$. unguicularis could come from the amino acids released by protein catabolism in this species during inanition. Acetyl CoA could derive from pyruvate (alanine, cysteine, cystine, glycine, serine and threonine) or directly from the aromatic amino acids phenylalanine, tyrosine, and tryptophan, and from lysine and leucine. Faecal excretion of potassium in O. unguicularis during dehydration (and starvation) was found to exceed the amount of potassium removed from the haemolymph over the same period by approx 7.5 times (S.G. Naidu, unpubl.). The excess potassium is most likely of intracellular origin, and probably results from protein-wasting in this species during the period of starvation.

The increase in the non-lipid dry material found in this species after drinking deserves further mention. Excretory metabolites such as allantoin, urea, and ammonia (despite its toxicity - Wigglesworth, 1972; Cochran, 1985), may be excreted and/or stored during the blood volume decrease of insect dehydration. When access to water is permitted, metabolism is increased and both newlyformed and stored excretory metabolites are extruded from tissues into an increased blood volume (Djajakusumah \& Miles, 1966). In O. unguicularis, excretory metabolites formed after drinking may not have the avenue of extrusion into the blood, since haemolymph volume in this species is not significantly increased $1 \mathrm{~h}$ after drinking. Haemolymph osmolality is also found not to have significantly changed at this time. It is possible that the $13 \mathrm{mg}$ increase in dry material found in this species after drinking may represent an accumulation of nonprotein nitrogen (excluding amino- $\mathrm{N}$ ) in tissues, which 
would accord with the extensive use of protein as an energy source during inanition.

That most water taken up (after drinking for $1 \mathrm{~h}$ ) may be stored by lipid synthesis in $O$. unguicularis, may explain why the haemolymph volume in this species is not greatly increased at this time (day 10, $1 \mathrm{~h}$ after drinking - Fig. 2A), and the considerably lower rate of water uptake in this species, relative to other similar-sized and even smaller species (S.G. Naidu, unpubl.). Small amounts of water may be taken up at a time, absorbed, and reconstituted by lipid synthesis in the fat body (and integument), before further water uptake occurs. Alternatively, water absorption from the gut may occur at a lower rate, to allow for lipid synthesis, thereby reducing the extent to which further water can be taken up. Broza et al. (1976) have found that a considerable proportion of the water taken up by the dehydrated tenebrionid Trachyderma philistina, is retained in the gut during the first day after drinking; and Coutchiè \& Crowe (1979a) have shown that water uptake in the larval tenebrionids Onymacris plana and Onymacris marginipennis ceases after a point, and have suggested that such control may be mediated by stretch receptors (Coutchiè \& Crowe, 1979b).

Synthesis of lipid in O. unguicularis appears to be related to a need to control the increase in haemolymph volume at this time, which in turn appears to be related to the poorer ability of this species to regulate haemolymph solute (and thence haemolymph osmotic pressure) during rehydration. Regulation of haemolymph volume is indicated $1 \mathrm{~h}$ after drinking, when no significant change is observed in this parameter, despite the consumption of $44.0 \mathrm{mg}$ of water. During the rehydration period, the haemolymph volume in $O$. unguicularis increases significantly only $48 \mathrm{~h}$ after access to water is first permitted. At this time, solute addition to the haemolymph is not great, and haemolymph OP falls substantially (by almost $40 \%$ of that expected in the complete absence of solute regulation). That $O$. unguicularis appears unable to mobilise solute efficiently when blood volume increases during rehydration (without food), may explain why the increase in haemolymph volume is restricted after drinking for $1 \mathrm{~h}$. Because of a relative inability to regulate haemolymph osmotic pressure (OP) by solute addition to the blood, control of haemolymph OP is effected by limiting the increase in haemolymph volume (possibly till the species is able to take up food). The blood volume increase (48 h after drinking) is not maintained when rehydration (no food) is extended: when examined $96 \mathrm{~h}$ after drinking, haemolymph volume is found to be subsequently reduced to immediate pre-rehydration values.

Although $O$. unguicularis demonstrates a capacity for osmoregulation during dehydration, this capacity is best suited to cope only with mild osmotic stress (up to 6 days of dehydration in the present study); regulatory efficiency deteriorates considerably when dehydration is prolonged (10 days), and haemolymph volume losses are greater. And, as noted above, the capacity to regulate haemolymph osmolality during drinking is relatively poor in this species. An osmoregulatory capability has previously been suggested for $O$. unguicularis, in a study in which haemolymph osmotic pressures in field beetles were found not to be significantly altered during periods when fogs did not occur (Cooper, 1982). Larvae (Machin, 1975; Coutchiè \& Crowe, 1979) and adult forms of other xeric beetles (Broza et al., 1976; Riddle et al., 1976; Nicolson, 1980; Cohen et al., 1986; Riddle, 1986; Naidu, 2001) also demonstrate regulation of haemolymph osmolality, and most of these show a similar propensity to regulate haemolymph osmolality more strongly during dehydration. Major osmolar effectors in the blood of $O$. unguicularis include sodium, chloride, trehalose and amino acids. There is regulation of all the measured constituents during dehydration in this species, with the major contributors to osmoregulation being decreases in haemolymph sodium, chloride, total sugar, and free amino acids. During rehydration (after drinking for $48 \mathrm{~h}$ ), major contributions to the increase in haemolymph total solute are made by amino acids, and an increase in the haemolymph content of solute(s) not measured in this study. Relatively minor contributions are made by sodium, potassium and glycerol.

Many mechanisms have been proposed to explain solute removal from the haemolymph during dehydration, and their subsequent replacement in the haemolymph during rehydration (Naidu, 2001). One of the mechanisms for the regulation of haemolymph amino acids during dehydration and rehydration, includes amino acid interchange with soluble protein (Djajakusumah \& Miles, 1966; Broza et al., 1976), and this possibility is examined further here. While the absolute amounts of haemolymph amino acids are found to decrease in O. unguicularis over the dehydration period, the absolute amounts of haemolymph proteins were also found to decrease over this time. Thus, the amino acids removed from the haemolymph during dehydration appear not to be sequestered as soluble protein in this species. And when initially allowed access to water $(1 \mathrm{~h})$, the increase in the absolute amino acid content was associated with little change in the absolute protein content at this time, and the further increase in the absolute amounts of haemolymph amino acids after $48 \mathrm{~h}$ of drinking was associated with an increase in the absolute amounts of haemolymph proteins. Thus, a source for amino acids other than their mobilisation from soluble protein appears to be evident during drinking in $O$. unguicularis. Also worth noting is the large increase in the haemolymph trehalose concentration of $O$. unguicularis, when rehydration (no food) is extended over 4 days (relative to immediate pre-rehydration values). Similar findings have been made for the adesmiine tenebrionids $S$. gracilipes and P. globosa (Naidu, 2001), and a similar large increase in the absolute amount of trehalose was found to accompany the haemolymph volume increase occasioned by rehydration in the adesmiine tenebrionid O. marginipennis larvae (Coutchiè \& Crowe, 1979). Mechanistic possibilities for sugar replacement in the haemolymph during drinking are wide-ranging (Newsholme \& Taylor, 1969; Coutchiè \& Crowe, 1979; Naidu, 1998). 
As noted earlier, O. unguicularis are peculiar among the diurnal Namib tenebrionid complement in their watercollecting behaviour from fogs (Hamilton \& Seely, 1976; Seely, 1979). Water gain in this way has been shown to be considerable, ranging from a mean of $14.5 \%$ of initial body weight (fog strength $=0.50 \mathrm{~mm}$ ) to a mean of approximately $2.1 \%$ of initial body weight (fog strength = $0.10 \mathrm{~mm}$ ); the maximum water gain by an individual was $34 \%$ of its body weight measured before the fog (Hamilton \& Seely, 1976).

Findings in the present study suggest that fog-basking behaviour in O. unguicularis may be related to the earlier development of osmotic stress in this species, relative to other diurnal dune tenebrionids with similar activity patterns e.g. O. plana (Holm \& Edney, 1973). O. unguicularis is a vagile species (as are other Onymacris adults Wharton, 1983), and is surface active during periods when the desiccatory nature of its environment is severe (particularly when wind cools the sand surface to approximately $50^{\circ} \mathrm{C}-$ Seely et al., 1983). Their elevated body temperatures are particularly conducive to the outward movement of water at these times by virtue of the increased effective vapour pressure difference. In addition, the water content of the detritus on which they feed is low (from 1-8\% - Seely, 1979), and Seely (1979) has determined that this amount of water is insufficient to maintain maximum foraging activity in this species. During diurnal surface activity in the absence of fogs, therefore, the potential for water loss appears to be great, possibly with overall water losses occurring each time $O$. unguicularis ventures out onto the surface. While such water losses may not be uncommon among diurnal dune tenebrionids with similar patterns of activity, however, osmoregulatory efficiency in $O$. unguicularis deteriorates considerably when blood loss approaches $40 \%$, as a result of which haemolymph OP increases greatly relative to the volume decrease. In $O$. plana, haemolymph OP is well regulated for haemolymph volume losses of up to $66 \%$ (Nicolson, 1980). Osmotic stress may thus develop sooner in $O$. unguicularis relative to $O$. plana (the total EWL rate in $O$. unguicularis is also considerably higher than that of $O$. plana at similar temperatures), and to a greater extent the longer the duration between fogs. The need to take up water may thus assume greater urgency in O. unguicularis, which may be related to the elaborate means adopted by this species for water uptake from fogs. That $O$. unguicularis possesses a significantly higher normal water content than other adesmiine and eurychorine species examined (Nicolson, 1980; Naidu, 1998, 2001) may be further related to osmoregulatory insufficiency when blood loss is relatively high i.e. the need to go for longer periods before osmoregulatory mechanisms are severely tested.

O. unguicularis demonstrates two important specializations which enable it to exploit Namib Desert fogs, and which may have contributed (at least in part) to the development of its fog-basking behaviour : (i) O. unguicularis possesses a blood glycerol level which is significantly higher than that of other diurnal species examined, and which is intermediate between that of the strictly nocturnal eurychorine $S$. stali and the diurnal adesmiine species Stenocara gracilipes, $O$. rugatipennis and Physadesmia globosa (Naidu, 1998, 2001). Glycerol, which causes depression of the supercooling point, is considered to be one of the most efficient cryoprotective compounds occurring naturally, and has been implicated in the overwintering ability or cold-hardiness (freezing tolerance) of many insects (Chino, 1957; Salt, 1959; Smith, 1961; Sømme, 1964, 1965; Doebbler, 1966; Asahina, 1966; Baust \& Miller, 1970; Storey \& Storey, 2005). Its considerable presence in the haemolymph of $O$. unguicularis (together with trehalose), therefore, would be of obvious significance to fog-basking during conditions which may otherwise preclude the presence of this species on the surface. Fogs as light as $0.1 \mathrm{~mm}$ on the Gobabeb fog-screen elicit fog-basking (Hamilton \& Seely, 1976), and fog-basking can occur at any time of the night when ambient temperatures may be lower than $3^{\circ} \mathrm{C}$ (Robinson \& Seely, 1980) and surface temperatures as low as $1^{\circ} \mathrm{C}$ (Seely, 1983) or sub-zero (Holm \& Scholtz, 1980). (ii) Water uptake and storage in O. unguicularis is associated with synthesis of fat. Despite it's poor ability to regulate haemolymph OP when confronted with a relative abundance of water, therefore, large amounts of water may be taken up and stored during fogs (when water uptake may be considerable - Hamilton \& Seely, 1976), without significantly increasing haemolymph volume and the attendant dangers of haemo-dilution (to be later released when the beetles are able to take up food). Such water storage would also be of benefit to the long-term water economy of this species: fog-basking could thus occur in the absence of osmotic stress, simply to replenish water reserves.

ACKNOWLEDGEMENTS. I wish to thank M.K. Seely for facilities made available to me at Gobabeb. My thanks are also due to the Foundation for Research and Development (FRD) for financial assistance, and to the SWA/Namibia Division of Nature Conservation for permission to carry out this work.

\section{REFERENCES}

Asahina E. 1966: Freezing and frost resistance in insects. In Merryman H.T. (ed.): Cryobiology. Academic Press, New York, pp. 451-484.

Baust J.G. \& Miller L.K. 1970: Variations in glycerol content and its influence on cold-hardiness in the Alaskan carabid beetle, Pterostichus brevicornis. J. Insect Physiol. 16: 979-990.

Broza M., Borut A. \& Pener M.P. 1976: Osmoregulation in the desert tenebrionid beetle Trachyderma philistina Reiche during dehydration and subsequent rehydration. Israel J. Med. Sci. 12: 868-871.

Chino H. 1957: Conversion of glycogen to sorbitol and glycerol in the diapause egg of the Bombyx silkworm. Nature 180: 606-607.

Cochran D.G. 1985: Nitrogenous excretion. In Kerkut G.A. \& Gilbert L.I. (eds): Comprehensive Insect Physiology Biochemistry and Pharmacology. Vol. 4. Pergamon Press, Oxford, New York, Toronto, Sydney, Paris, Frankfurt, pp. 467-506.

Cohen A.C., March R.B. \& Pinto J.D. 1986: Effects of water stress and rehydration on hemolymph volume and amino acid 
content in the blister beetle, Cysteodemus armatus. Comp. Biochem. Physiol. (A) 85: 743-746.

COOPER P.D. 1982: Water balance and osmoregulation in a freeranging tenebrionid beetle, Onymacris unguicularis, of the Namib Desert. J. Insect Physiol. 28: 737-742.

Coutchiè P.A. \& Crowe J.H. 1979a: Transport of water vapor by tenebrionid beetles. I. Kinetics. Physiol. Zool. 52: 67-87.

Coutchiè P.A. \& Crowe J.H. 1979b: Transport of water vapor by tenebrionid beetles. II. Regulation of the osmolarity and composition of the haemolymph. Physiol. Zool. 52: 88-100.

Djajakusumah T. \& Miles P.W. 1966: Changes in the relative amounts of soluble protein and amino acid in the haemolymph of the locust, Chortoicetes terminifera Walker, in relation to dehydration and subsequent hydration. Aust. J. Biol. Sci. 19: 1081-1094.

DoebBlER G.F. 1966:. Cryoprotective compounds: Review and discussion of structure and function. In Merryman H.T. (ed.): Cryobiology. Academic Press, New York, pp. 2-11.

Edney E.B. 1957: The Water Relations of Terrestrial Arthropods. Monographs in Experimental Biology 5, Cambridge University Press, Cambridge, 109 pp.

EDNey E.B. 1977: Water Balance in Land Arthropods. Springer, Berlin, Heidelberg, New York, 282 pp.

Hamilton W.J. 1975: Coloration and its thermal consequences for diurnal desert insects. In Hadley N.F. (ed.): Environmental Physiology of Desert Organisms. Dowden, Hutchinson and Ross, Stroudsburg, Pennsylvania, pp. 67-89.

Hamilton W.J \& Seely M.K. 1976: Fog basking by the Namib Desert beetle, Onymacris unguicularis. Nature 262: 284-285.

Hattingh J., Ganhao M.F. \& Naidu S.G. 1984: Haemolymph composition in Namib Desert tenebrionid beetles. Comp. Biochem. Physiol. (A) 78: 541-545.

Holm E. \& Edney E.B. 1973: Daily activity of Namib Desert beetles in relation to climate. Ecology 54: 45-56.

Holm E. \& Scholtz C.H. 1980: Structure and pattern of the Namib Desert dune ecosystem at Gobabeb. Madoqua 12(1): 3-39.

LEVENBOOK L. 1958: Intracellular water of larval tissues of the Southern Armyworm as determined by the use of ${ }^{14} \mathrm{C}$ carboxyl inulin. J. Cell. Comp. Physiol. 52: 329-339.

Louw G.N., Nicolson S.W. \& Seely M.K. 1986: Respiration beneath desert sand: carbon dioxide diffusion and respiratory patterns in a tenebrionid beetle. J. Exp. Biol. 120: 443-447.

Lowry O.H., Rosenbrough N.J., Farr A.L. \& Randall R.J. 1951: Protein measurement with the Folin phenol reagent. $J$. Biol Chem. 193: 265-275.

Machin J. 1975: Water balance in Tenebrio molitor L. larvae: The effect of atmospheric water absorption. J. Comp. Physiol. 101: 121-132.

NAIDU S.G. 1998: Haemolymph amino acid, sugar and glycerol levels in the Namib Desert tenebrionid Stips stali during dehydration and rehydration. Comp. Biochem. Physiol. 119: $477-484$.

NAIDU S.G. 2001: Water balance and osmoregulation in Stenocara gracilipes, a wax-blooming tenebrionid beetle from the Namib Desert. J. Insect Physiol. 47: 1429-1440.

Newsholme E.A. \& Taylor K. 1969: Glycerol kinase activities in muscles from vertebrates and invertebrates. Biochem. J. 112: $465-474$.

NiCOLSON S.W. 1980: Water balance and osmoregulation in Onymacris plana, a tenebrionid beetle from the Namib Desert. J. Insect Physiol. 26: 315-320.
Richardson C.H., Burdette R.C. \& Eagleson C.W. 1931: The determination of the blood volume of insect larvae. Ann. Entomol. Soc. Am. 24: 503-507.

RidDLE W.A. 1986: Hemolymph osmoregulation in three species of beetles. Comp. Biochem. Physiol. 83: 619-626.

Riddle W.A., Crawford C.S. \& Zeitone A.H. 1976: Patterns of hemolymph osmoregulation in three desert arthropods. $J$. Comp. Physiol. 112: 295-305.

Robinson M.D. \& Seely M.K. 1980: Physical and biotic environments of the southern Namib dune ecosystem. J. Arid Env. 3: $183-203$.

Salt R.W. 1959: Role of glycerol in the cold-hardening of Bracon cephi (Gahan). Can. J. Zool. 37: 59-69.

Scheurer R. \& Leuthold R. 1969: Haemolymph proteins and water uptake in female Leucophaea maderae during the sexual cycle. J. Insect Physiol. 15: 1067-1077.

SEeLY M.K. 1979: Irregular fog as a water source for desert dune beetles. Oecologia (Berl.). 42: 213-227.

SeELY M.K. 1983: Effective use of the desert dune environment as illustrated by the Namib tenebrionids. In Lebrun P., André H.M., De Medts A., Gregoire-Wibo C. \& Wauthy G. (eds): Proceedings of the VIII International Colloquium of Soil Zoology. Dieu-Brichart, Ottignies-Louvain-la-Neuve, pp. 357-368.

Seely M.K., Lewis C.J., O’Brien K.A. \& Suttle A.E. 1983: Fog response of tenebrionid beetles in the Namib Desert. J. Arid Env. 6: 135-144.

SeEly M.K., Roberts C.S. \& Mitchell D. 1988: High body temperatures of Namib dune tenebrionids - why? J. Arid Env. 14: $135-143$.

Sмiтн A.U. 1961: Biological Effects of Freezing and Supercooling. Williams and Wilkins, Baltimore, $462 \mathrm{pp}$.

Sømme L. 1964: Effects of glycerol on cold-hardiness in insects. Can. J. Zool. 42: 87-101.

Søмme L. 1965: Further observations on glycerol and coldhardiness in insects. Can. J. Zool. 43: 765-770.

Storey K.B. \& Storey J.M. 2005: Freeze tolerance. In Gerday C. \& Glansdorff N. (eds): Extremophiles. Eolss Publishers, Oxford, UK, pp. 1-24.

TUCKER L.E. 1977a: Effect of dehydration and rehydration on the water content and $\mathrm{Na}^{+}$and $\mathrm{K}^{+}$balance in adult male Periplaneta americana. J. Exp. Biol. 71: 49-66.

TUCKER L.E. 1977b: The influence of age, diet and lipid content on survival, water balance and $\mathrm{Na}^{+}$and $\mathrm{K}^{+}$regulation in dehydrating cockroaches. J. Exp. Biol. 71: 81-93.

Van Handel E. 1965: The obese mosquito. J. Physiol. 181: 478-486.

VERRET J.M. \& MiLLS R.R. 1973: Water balance during vitellogenesis by the American cockroach: translocation of water during the cycle. J. Insect Physiol. 19: 1889-1901.

VeRRET J.M. \& MiLls R.R. 1975a: Water balance during vitellogenesis by the American cockroach: hydration of the oocytes. J. Insect Physiol. 21: 1061-1064.

VerRet J.M. \& Mills R.R. 1975b: Water balance during vitellogenesis by the American cockroach: distribution of water during the six day cycle. J. Insect Physiol. 21: 1841-1845.

WALL B.J. 1970: Effects of dehydration and rehydration on Periplaneta americana. J. Insect Physiol. 16: 1027-1042.

WHARTON R.A. 1983: Dispersal, diel periodicity, and longevity of Stips stali (Haag) (Coleoptera: Tenebrionidae). Coleopt. Bull. 37: 27-33.

Wigglesworth V.B. 1972: The Principles of Insect Physiology. Chapman and Hall, London and New York, 827 pp.

Received May 20, 2008; revised and accepted September 8, 2008 